\title{
Human Capital, Self-Efficacy and Firm Performance: A Study of Bumiputera SMEs in Malaysia
}

\author{
Nurul Naziha Zuhir ${ }^{1}$, Ehsan Fansuree Surin ${ }^{1} \&$ Hardy Loh Rahim $^{1}$ \\ ${ }^{1}$ Faculty of Business and Management, Universiti Teknologi MARA (UiTM), Selangor, Malaysia \\ Correspondence: Nurul Naziha Zuhir, Faculty of Business and Management, Universiti Teknologi MARA (UiTM), \\ 42300 Puncak Alam, Selangor, Malaysia.
}

Received: July 31, 2019

doi:10.5430/ijfr.v10n6p218
Accepted: August 28, 2019

Online Published: September 8, 2019

URL: https://doi.org/10.5430/ijfr.v10n6p218

\begin{abstract}
SMEs represent more than 90 percent of the establishment in many countries including Malaysia. However, from 98.5 percent of SMEs establishment, only 37 percent represent bumiputera SMEs. Human capital and self-efficacy are identified as internal factors of the organisation and function as a possible solution to address bumiputera SMEs' difficulties. Hence, the primary objective of this study is to investigate the mediating effect of self-efficacy in the interaction between human capital and the SMEs performance in Malaysia. This study has investigated 203 Malay-owned small and medium enterprises. Structural Equation Modelling (SEM) was employed to analyse the data. The results demonstrated that human capital and self-efficacy influence each other and have a significantly positive impact on firm performance. Mediation simultaneously affirms that the relationship between human capital and firm performance is mediated by self-efficacy. This study concluded that these two internal factors can provide a holistic model to improve bumiputera SMEs performance in Malaysia.
\end{abstract}

Keywords: human capital, self-efficacy, bumiputera SME firm performance

\section{Introduction}

SMEs are indeed assumed as a focal driver to the economic growth, since it made up a vast majority of the population all over the world in most countries. Specifically, they accounted 98.5 percent from total business establishment in Malaysia. The SMEs was seen to resolute where they contributed 37.1 percent to GDP, 66 percent to the total employment and 17.3 percent to the overall export in 2017 (SME Corp Malaysia, 2017). Apparently, Malaysian economy has seen a remarkably improvement in their performance. Since economy is shifting to the next level to attain high-income status, Malaysian government has depended greatly on SMEs to push its contribution to 42 percent GDP by 2020. Consequently, every SMEs in Malaysia especially bumiputera SMEs need to make a possible effort to push Malaysia to move forward on a journey to achieve a fully developed economy. In order to do so, it is important to build a strong and resilient bumiputera SMEs to ensure that their contribution match non-bumiputera contribution to the GDP by 2020. Bumiputera is also known as the son of the soil of Nusantara or more commonly known as Malaysia (Anwar, Husain, Bakar \& Zakaria, 2012). Since bumiputera constitutes a majority of the Malaysian population, this achievement has become a concern for the Malaysian government. The Malaysian government is committed to strengthening the bumiputera economy by providing a variety of incentives to encourage them. In the Eleventh Malaysia Plan (11MP), the government has allocated RM500 million to intensify the development of bumiputera. One of the programmes to be implemented is by empowering the bumiputera Economic Community. The programmes to be implemented basically aim to empower the bumiputera human capital. This shows that the government is taking this predicament seriously. As a result, bumiputera SMEs are expected to increase their participation in the economy and their competitiveness in the business market.

Although the government has provided numerous initiatives, financial difficulty is still the leading predicament that prevents the bumiputera SMEs to grow (Eleventh Malaysia Plan [11MP], 2015; Omar \& Azmi 2016). According to Thaker and Mohammed (2015), micro enterprise always experienced difficulties in receiving considerable funding from the financial institution. In particular, the lack of qualified demand has caused financial institutions to neglect lending to SMEs (Ramlee, 2013). Due to this, the micro sectors always lack in proper attention and financial assistance to develop and survive (Thaker \& Mohammed, 2015). Hence, the bumiputera spirit or resilience to continue their business gradually fades. Consequently, the economic control remains unequal as the number of 
bumiputera participation in professional and economic industries is small (Said et al. 2018). This study argues that insufficient finance and access to credit seems to become a root cause besiege the bumiputera for their development and survivals. Ishak, Omar, Othman and Ahmad (2012) supported that lack in capital will cause a bunch of problems such as the inability to adopt a new technologies, human capital deficiency, low product quality and poor quality of raw material. Therefore, bumiputera SMEs need more creativity to search for other alternatives solution.

Realising the intense challenges and competition that Malaysia will face in the new economy, it is important to ensure the bumiputera capability to develop their competitive advantage to meet those challenges. According to SME Corp Malaysia (2017), the continuous challenges SMEs faced is mainly caused by the innovation and technology adoption, human capital development, access to financing, market access, legal and regulatory environment. However, for the sake of this paper, only the development of human capital and other factor that can be used in conjunction will be focused. Particularly, this present study will focus on the human capital relationship with firm performance through its role in developing self-efficacy. As human capital contributes to self-confident, opportunity recognition and risk management, which are the antecedents of self-efficacy, there is a reason to suggest that there could be a positive relationship with firm performance.

\section{Literature Review}

\subsection{Bumiputera SMEs Performance}

The SMEs in Malaysia are classified according to three categories namely; micro, small and medium enterprises. The largest component of SMEs in Malaysia constitutes the microenterprise where they account for 76.5 percent of the total establishment (Department of statistic Malaysia, 2011). The remaining 21.2 percent and 2.3 percent constitute the small and medium enterprises. It should be acknowledged that; from the 98.5 percent of SMEs establishment, only 37 percent constitutes bumiputera SMEs, and 90 percent of bumiputera SMEs were in micro sectors. The various government incentives that have been implemented to attract bumiputera to venture entrepreneurship have somehow resulted to be effective in increasing their participation in the business world. According to Zainol, Shokory, Osman and Samsudin (2018), bumiputera corporate equity has increased from 2.4 percent in 1970 to 21.9 percent in 2009. It has indeed increased the number of bumiputera participation in business; however, they need to ensure their development and sustainability by improving their competitive advantage to pass the new economic challenges. Although the New Economic Policy (NEP) was seen to succeed in bringing the bumiputera participation into business, unfortunately it has failed to stimulate the development and resilient among them (Whah \& Guan, 2017). Consequently, many of the bumiputera businesses failed (Kadir, 2012). Bumiputera SMEs contributed only 13 percent out of 30 percent to the total SMEs contribution to the national GDP (Chin, 2018). According to Ishak et al. (2012), to maintain business is not as easy as to start the business. The bumiputera achievements have not yet reach a satisfactory level (Zainol et al., 2018). The economic disparity between bumiputera and non-bumiputera were also large even though they made up a majority of population. Zainol et al. (2018) added that the involvement in entrepreneurial activities among bumiputera is also insignificant. Therefore, in achieving vision 2020, every SME in Malaysia including those of bumiputeras' need to put a hefty effort so that the contributions to the economic are equal among other ethnics.

\subsection{Human Capital}

Human capital is a term that was initially derived from Theodore W. Schultz in 1961 who assessed human capital from an economic point of view. Human capital is referred to as a determinant of future earnings and satisfaction as explained by Schultz (1961). Becker (1975) defined human capital as skill, knowledge, value, and health that are distinctive from the physical and financial asset. Physical capital is important but is no longer a sustainable competitive advantage (Munjuri \& K'Obonyo, 2015). Subsequently, the definition was further developed across industries, countries, and culture. Coff (1997) highlighted that human capital is a competitive advantage that is difficult to emulate. Liu \& Wang (2013) view human capital as the skill, knowledge as well as ability possessed by humans that are high in monetary value. It seems that economic growth and development depend on human capital value such as knowledge that drives the economy (Azizan, 2013). Human capital has long been acknowledged as a source of competitive advantages (Hilmi, Ramayah, Hassan \& Mustapha, 2010).

\subsection{Self-Efficacy}

Bandura (1977) defined self-efficacy as an individual's confidence in his or her competence to complete an action needed to attain a goal effectively. Stajkovic and Luthans (2003) have defined self-efficacy as a self-confidence which will positively influence human resources. Meanwhile, Luszczynska, Gutiérrez-Doña, \& Schwarzer (2005) defined self-efficacy as the belief in one competence to handle with difficulty, stress, or strenuous experience to 
accomplish objectives. Self-efficacy is one's confidence in an individual's ability to actualise a specific task and carry out actions to complete the selected performance (Shane, Locke \& Collins, 2003; Kadir 2012). Raza, Zia, Naqvi, \& Shaikh (2011) defined self-efficacy as positive psychological capital (confidence, hope and optimism) that is generated from the human capital (knowledge, skills and experience).

\section{The Resource-Based View Theory (RBV)}

The RBV theory is relevant in explaining the problem experienced by SMEs. This theory stipulates that heterogeneity resources are crucial in maintaining long-term survival. Campbell, Coff and Kryscynski (2012) contended that human capital is one of the heterogeneity resources that cannot be easily imitated by other competitors. On the other hand, human capital can mobilise motivation and display an adaptive organisation. It is viewed that psychological capital (self-efficacy) and human capital are in accordance with the essence of RBV theory (Luthans, Luthans \& Luthans, 2004). It is widely recognised that SMEs often experience financial constraints that obstruct their development (Kalianan, Abraham \& Ponnusamy, 2016). Nevertheless, the reinforcement in internal resources limits the firms' reliance on financial capital to achieve firm success (Radzi, Nor \& Ali, 2017). The pressure presented in the external environment, to some extent reduces the motivation and indirectly causes a firm to lose its critical assets (Coff 1997). Hence, there is a need to strengthen the internal resources of organisations to pursue the designated goals. Ahmad and Seet (2009) postulated that the negative impact of the external environment can be minimised with the utilisation of relevant abilities and skills presented in human capital. Concurrently, Alam, Mohd, Hisham \& Nor (2015) added that an individual with high self-efficacy is capable of neutralising these constructive criticisms positively. Therefore, this study categories both resources as internal factors, which are believed to influence the performance.

\subsection{Hypotheses Development}

The relationship between human capital and firm performance has been an area of interest for both researcher and practitioners. Despite the considerable amount of research has proven the significant and positive relationship between these variables, some of the recent studies have found that this relationship is insignificant. Previous study argued that human capital does not have a direct relationship with firm performance (Hooi \& Ngui, 2013). Therefore, this relationship was considered ambiguous and it needs further investigation.

A significant amount of research proves that human capital has an impact on performance. For example, Sharabati, Naji Jawad \& Bontis (2010) investigated the effect of intellectual capital, which comprises of human capital, structural capital, and relational capital. The results showed that human capital has positively affected the performance of pharmaceutical sectors in Jordan. The study by Unger, Rauch, Frese and Rosenbusch (2011) has investigated the relationship between human capital and success. The results revealed that the outcomes of human capital investment showed a high relationship as compared to human capital investment. Samad (2013) proved that human capital value such as training and education, knowledge and skills, competencies and creativity and attitude contributed significantly to the performance of Malaysian logistic companies. Another similar study was done by Rahim, Atan and Kamaluddin (2016) and it investigated the role played by human capital efficiency on Malaysian technology industries. The result demonstrated that human capital efficiency was significant and it has been simultaneously concluded that human capital is more beneficial than others.

Although human capital is known to have a significant impact on firm performance, this relationship was also found insignificant by many previous studies in the same area of study. For example, the study done by Khalique, Shaari, Abdul, Isa and Ageel (2011) on the role of intellectual capital of electric and electronic in Pakistan revealed the results of multiple regression presented that human capital showed insignificant contribution in enhancing the performance electric and electronic industries in Pakistan. The author also expanded their study in other contexts such as in Malacca and Penang. However, the result seems to be consistent with their previous study where human capital was found insignificant in contributing to the firm performance (Khalique \& Mansor, 2016; Khalique, Shaari, Abdul \& Isa, 2018). Other study done by Hashim, Osman and Alhabshi (2015) investigated the effect of intellectual capital on firm performance. The analysis shows a similar result where all the elements in intellectual capital were found significant except human capital. The discrepancy in the empirical results is startled, leading this future study to investigate more on this relationship. This may be due to either those SMEs were not giving a sufficient effort to enhance their human capital or human capital needs other factors such as self-efficacy to intensify performance. Hence, it can be concluded that;

$H_{1}$ : Human capital has a significant positive effect on bumiputera SMEs performance 
The study on the relationship between human capital and self-efficacy was seems limited. Meanwhile, this relationship was considered to be rarely studied especially in a non-western country particularly in Malaysia. This study believes that the impact of human capital on firm performance is redoubled when an individual in the firm is confident at every step. In the case of bumiputera SMEs, the weaknesses in knowledge and skills are frequently quoted as degradability to the development of bumiputera SMEs in Malaysia (Tunggak, Salamon \& Abu, 2011). Meanwhile, bumiputera SMEs habitually seems to experience ideas shortage, which consequently hinders them from innovating, preserving, and taking risks. Consequently, they felt that the challenges and competition were intense (Abidin, Harun \& Rahman, 2014). This will gradually reduce their interest and thus simultaneously diminish their effort to reach their goals. Coff (1997) argued that firms are unable to attain a viable competitive advantage from human assets if they are unable to manage the related quandary state, which could exert low effort.

Human capital plays an important part in enhancing self-efficacy. According to Mohd, Kamaruddin, Hassan and Muda (2014), self-efficacy can be developed through the development in education and training that can improve entrepreneurial activities. Raza et al. (2011) revealed that the skill, competency, and ability are not the components of self-efficacy but are the impetus that can improve self-efficacy that forecast the actions to achieve the envisioned objectives. The study strongly recommended the development of human capital for self-efficacy. Therefore, human capital may require self-efficacy to enable continuous effort, and self-efficacy may need human capital to improve the level of confidence in making the right decision.

Oyugi (2016) has investigated on the relationship between entrepreneurship education and self-efficacy. This study has been done among university students. The study assumed that entrepreneurial education and self-efficacy can be developed to enhance the entrepreneurial intention among university students. The results supported the hypothesis where entrepreneurial education has positively affect self-efficacy.

This study also believes that with the mastery of the relevant knowledge and skills, hence self-efficacy will be increased and simultaneously prepared a person to commit to doing something (Bandura, 1986). The value contained in self-efficacy plays a critical role in how goals, tasks, and challenges are approached. In this situation, human capital and self-efficacy are complementary in affecting firm performance. Therefore, the following hypotheses are formulated:

\section{$\mathrm{H}_{2}$ : Human capital has a significant positive effect on self-efficacy}

Research on self-efficacy with and its influence on firm performance are scarce. Most of the prior research has placed focus on the relationship between self-efficacy and relevant educational performance. Moreover, there is minimal literature that examines the influence of self-efficacy on firm performance in the Malaysian context, particularly among bumiputera SMEs (Sabiu \& Abdullah 2017). Hence, this study is vital to ensure that this gap in the literature is addressed.

Research on self-efficacy found that an individual with high self-efficacy finds challenges excited, are interested in participating in activities, has fast recovery from setbacks, and is more committed than those with low self-efficacy (Mohd et al. 2014). Several studies presented a significant relationship between self-efficacy and firm performance. Oyugi (2016) identified a positive association between self-efficacy and organizational performance. The study pointed out that self-efficacy is capable of making an individual stronger in solving a challenge, especially in a high-risk setting. Chen Gully and Eden (2004) stated that self-efficacy plays an important role in identifying the level of effort that someone must put, and perseverance to cope with different situations. Cherian and Jacob (2013) emphasised that self-efficacy will certainly improve business efficiency. The study apprehended the individual persistence in their propensity to view oneself as capable or incapable in meeting task demands in every situation (Cherian and Jacob 2013). Meanwhile, the complexity of the task and diverse situation may also weaken the relationship between self-efficacy and firm performance (Stajkovic and Luthans 1998). However, people with sufficient abilities believe that they are able to deal with difficulties.

Mohd et al. (2014) argued that an individual who possesses high self-efficacy views challenges as new opportunities while an individual who possesses lower self-efficacy has a tendency to evade difficult tasks. Hence, self-efficacy is crucial in explaining firm performance. Previous studies on bumiputera revealed that they are striving to overcome challenges and struggling to remain competitive with other races. Besides, Abdullah, Hamali, Deen, Saban, and Abdurahman et al. (2009) argued on the lack of resilience and efficiency among bumiputera which consequently hinder them to compete globally and even among other races. This study responds to calls for emphasised in terms of the need of motivation to enhance bumiputera competitiveness (Sabiu and Abdullah, 2017). Therefore, it can be concluded that: 


\section{$H_{3}$ : Self-efficacy has a significant positive effect on bumiputera SMEs performance}

Previous studies demonstrated significant positive relationships among these variables. The first relationship is self-efficacy has a significant positive effect on firm performance and the second relationship is that human capital has a significant positive effect on firm performance. Besides, the link between human capital and firm performance remain ambiguous even though a bunch of the previous studies offered a significant and positive relationship between these variables. This study claims that; a person could not be able to achieve their goals without self-efficacy. Without this value, a motivation can wane, the interest gradually fades and they are not committed in pursuing their goals. This is because, the value in self-efficacy are able to regulate a person's behavior to reach the goals. However, an optimum self-efficacy can only be gained from the development in human capital. The mediating role of self-efficacy with respect to the human capital and firm performance is rarely studied. Mohamad, Rizal, Quobab, Juhdi and Sahimi (2016) indicated that internal factors such as knowledge, skills, and motivation are known to contribute to a firm's resilience among bumiputera because it can develop a competitive advantage. Based on the literature, this study expects that the overall impact of human capital on firm performance is strengthened through its role on intensifying self-efficacy. It can be concluded that human capital is indirectly affecting firm performance through mediating variable that is self-efficacy. Thus, the following hypotheses are proposed:

$H_{4}$ : Self-efficacy mediates the relationship between human capital and bumiputera SMEs performance.

Table 1. Summary of the chosen past studies

\begin{tabular}{|c|c|c|c|}
\hline Past studies & $\begin{array}{l}\text { Direct relationship } \\
\text { Independent (ID) } \\
\text { Dependent (D) }\end{array}$ & Study origin & $\begin{array}{l}\text { Profit/non-profit } \\
\text { sectors }\end{array}$ \\
\hline $\begin{array}{l}\text { Sharabati, Naji Jawad and } \\
\text { Bontis (2010) }\end{array}$ & $\begin{array}{l}\text { ID: Human capital } \\
\text { D: Firm performance }\end{array}$ & Jordan & Profit sector \\
\hline $\begin{array}{l}\text { Hilmi, Ramayah, Hassan, and } \\
\text { Mustapha (2010). }\end{array}$ & $\begin{array}{l}\text { ID: Human capital } \\
\text { D: Firm performance }\end{array}$ & Malaysia & Profit sector \\
\hline $\begin{array}{l}\text { Rahim, Atan and Kamaluddin } \\
\text { (2017) }\end{array}$ & $\begin{array}{l}\text { ID: Human capital } \\
\text { D: Firm performance }\end{array}$ & Malaysia & Profit sector \\
\hline Khan and Quaddus (2018) & $\begin{array}{l}\text { ID: Human capital (demographic } \\
\text { factors and psychographic factors) } \\
\text { D: Firm performance }\end{array}$ & Bangladesh & Profit sector \\
\hline Hmieleski and Carr (2008) & $\begin{array}{l}\text { ID: Human capital, Psychological } \\
\text { capital self-efficacy) } \\
\text { D: Firm performance }\end{array}$ & US & Profit sector \\
\hline Cherian and Jacob (2013) & $\begin{array}{l}\text { ID: Self-efficacy } \\
\text { D: Motivation and employee } \\
\text { performance }\end{array}$ & UAE & Profit sector \\
\hline Past studies & Indirect relationship & Study origin & $\begin{array}{l}\text { Profit/non-profit } \\
\text { sectors }\end{array}$ \\
\hline Yusuf (2011) & $\begin{array}{l}\text { ID: Self-efficacy } \\
\text { D: Self-regulated learning } \\
\text { strategies } \\
\text { M: Achievement motivation }\end{array}$ & Malaysia & Non-profit sector \\
\hline $\begin{array}{l}\text { Raza, Zia, Naqvi and Shaikh } \\
\text { (2011) }\end{array}$ & $\begin{array}{l}\text { ID: Human and social capital } \\
\text { D: Performance of universities } \\
\text { M: Self-efficacy }\end{array}$ & Pakistan & Non-profit sector \\
\hline Pihie and Bagheri (2013) & ID: Self-efficacy & Malaysia & Non-profit sector \\
\hline
\end{tabular}




\begin{tabular}{|c|c|c|c|}
\hline & D: Entrepreneurial intention & & \\
\hline & M: Self-regulation & & \\
\hline Hooi and Ngui (2014) & ID: Human resources & Malaysia & Profit sector \\
\hline & D: Organisational learning & & \\
\hline & M: Firm Performance & & \\
\hline $\begin{array}{l}\text { Mohd, Kamaruddin, Hassan, } \\
\text { Muda and Yahya (2014) }\end{array}$ & $\begin{array}{l}\text { ID: Human value (education and } \\
\text { training) }\end{array}$ & Malaysia & Profit sector \\
\hline & D: Entrepreneurial orientation & & \\
\hline & M: Self-efficacy & & \\
\hline Khedhaouria, Gurău and & ID: Creativity and self-efficacy & French & Profit sector \\
\hline & D: Employee performance & & \\
\hline & M: entrepreneurial orientation & & \\
\hline Oyugi (2016) & ID: Entrepreneurship education & Uganda & Non-profit sector \\
\hline & D: Entrepreneurship intention & & \\
\hline & M: Self-efficacy & & \\
\hline Barbaranelli, & ID: Positivity & Italy & Profit sector \\
\hline $\begin{array}{l}\text { Biagioli, } \quad \text { Fida } \\
\text { Tramontano (2018) }\end{array}$ & $\begin{array}{l}\text { D: Firm performance } \\
\text { educational setting }\end{array}$ & & \\
\hline & M: Self-efficacy & & \\
\hline
\end{tabular}

Table 1 presented the chosen past studies articles in the area of human capital, self-efficacy and performance. The table indicates that the studies on self-efficacy are considered as literally small in Malaysia as most of the previous study was done in a non-profit sector. In addition, most of the previous studies focusing on the direct relationship between these variables i.e human capital and firm performance, self-efficacy and firm performance. Hence, this present studies aimed to contribute to the existing literature by integrating human capital, self-efficacy and firm performance as a cohesive framework.

\section{Methods}

\subsection{Sample and Data Collection}

Convenience sampling was utilised in this study. This sampling method was chosen based on several reasons. The first reason is due to the simplicity of the sampling as the aim of this study is to understand the relationship between the variables. The second reason for the selection of this sampling method is due to the time and cost constraints. Email was utilised to distribute the questionnaires. A link to the online questionnaire was also provided to the respondents which helped to reduce the distribution cost. Feedback from bumiputera SME companies was required in this study; hence, organisation is the unit of analysis in this study.

To increase the response rate, a telephone enquiry was done to remind the respondents. Besides, questionnaires were distributed during the Small and Medium Industries Development Exhibition (SMIDEX), Kuala Lumpur, Malaysia in October and December 2017. This event comprises all SME companies from all states in Peninsular Malaysia including Sabah and Sarawak. From a total of 850 questionnaires, only 203 questionnaires were valid to be used which represent a 24 percent response rate.

\subsection{Descriptive Analysis}

Overall, more than 50 percent of the respondents in this study were sole proprietorship, 22.2 percent were private limited, and 16.3 percent were partnership. The participants were found having less than 200 full-time workers. Table 1 depicts that two states, namely, Selangor and Kuala Lumpur $(\mathrm{KL})$ are the epicentres of SMEs in this study that represent nearly 70 percent respondents, followed by Northern Peninsular by 12.8 percent, East Coast Peninsular by 8.4 percent, Southern Peninsular 6.9 by percent, and Sabah and Sarawak by 3.9 percent. 
Table 2. Descriptive statistics

\begin{tabular}{|c|c|c|}
\hline Profile & Number of respondents & Valid percentage $(\%)$ \\
\hline \multicolumn{3}{|l|}{ Ownership status } \\
\hline Sole proprietor & 125 & 61.6 \\
\hline Partnershi & 33 & 16.3 \\
\hline Private limited & 45 & 22.2 \\
\hline \multicolumn{3}{|l|}{ Geographical Location } \\
\hline $\begin{array}{l}\text { Northern Peninsular Malaysia (Perak, Penang, Perlis, } \\
\text { Kedah) }\end{array}$ & 26 & 12.8 \\
\hline $\begin{array}{llll}\begin{array}{l}\text { Central } \\
\text { Persekutuan }(\mathrm{KL})\end{array} & \text { Malaysia } & \text { (Selangor, } & \text { Wilayah } \\
\end{array}$ & 138 & 68 \\
\hline $\begin{array}{l}\text { East Coast Peninsular Malaysia (Pahang, Terengganu, } \\
\text { Kelantan) }\end{array}$ & 17 & 8.4 \\
\hline $\begin{array}{l}\text { Southern Peninsular Malaysia (Negeri Sembilan, Melaka, } \\
\text { Johor) }\end{array}$ & 14 & 6.9 \\
\hline East Malaysia (Sabah, Sarawak) & 8 & 3.9 \\
\hline
\end{tabular}

Table 2 presented the ownership status and geographical location of the respondents from this study.

\subsection{Measures}

The questionnaire consists of four parts. The first section is Section A which consists of 11 items of HC. The second part is Section B and it consists of 8 items of SE and Section C consists of 5 items of FP. The fourth section of the questionnaire inquired about the background of the company which consists of 10 items. The questionnaire adapted the instrument developed from previous studies in the field of HC, SE and FP. The construct of HC was measured using 3 dimension adopted from Sharabati et al. (2010). All the items in HC were measured in terms of learning and education, experiences and expertise, and innovation and creation. In total, 11 items were used to measure the HC construct. The SE dimension was measured after adapting the instrument developed by Kadir (2012). The SE variable was measured in terms of risk management skills, financial management skills as well as management and marketing skills. In total, 8 items were used to measure the SE construct. The firm performance dimension was measured based on the instrument developed by Gold, Malhotra and Segars (2001), Ngah (2011). The firm performance was measured in terms of growth, profit and sales. In total, 5 items were used to measure the firm performance construct. A 5-point Likert scale was used to measure the three variables where the scale ranged from "1 - strongly disagree" to "5 - strongly agree".

\subsection{Data Analysis and Results}

There are two stages involved in analysing the data in this study as suggested by previous study (Anderson and Gerbing, 1988). Structural Equation Modelling (SEM) was employed to test the model developed in the first stage with the aim of minimising the errors variance (Hair et al. 2006). For this purpose, the confirmatory factor analysis (CFA) using AMOS 23 was utillised to measure whether or not the variable and loadings factor meet the expectations. The CFA analysis is useful to cleanse errors hence providing the estimated relationship among latent variables that are less contaminated by measurement errors (Christ, Lee, Lam \& Zeng, 2014). In the second stage, the Structural Equation Modelling (SEM) analysis was further employed to test the hypothesis in the second stage. The AMOS programme was selected to test the mediation effect by analysing all path linkages in the model.

\subsubsection{Measurement Model}

Reliability, convergent validity, and discriminant validity were examined using confirmatory factor analysis (CFA). At the first phase, the result found are inconsistent and was unsatisfactory with the specified measurement model. This study further reanalyzed it to achieve a good fit model as recommended by Anderson and Gerbing (1988). The CFA analysis revealed that 6 items need to be dropped in human capital, 4 items to be dropped in self-efficacy and 1 item to be dropped in firm performance. 
Table 3. Measurement model

\begin{tabular}{|c|c|c|c|c|}
\hline Construct & Items & Loadings & Composite Reliability (CR) & $\begin{array}{l}\text { Average Variance Extracted } \\
\text { (AVE) }\end{array}$ \\
\hline \multirow[t]{5}{*}{ Human capital } & SA1 & 0.88 & \multirow[t]{5}{*}{0.92} & \multirow[t]{5}{*}{0.76} \\
\hline & SA4 & 0.59 & & \\
\hline & SA5 & 0.84 & & \\
\hline & SA6 & 0.85 & & \\
\hline & SA9 & 0.91 & & \\
\hline \multirow[t]{4}{*}{ Self-efficacy } & SB2 & 0.88 & \multirow[t]{4}{*}{0.91} & \multirow[t]{4}{*}{0.61} \\
\hline & SB3 & 0.85 & & \\
\hline & SB5 & 0.86 & & \\
\hline & SB6 & 0.89 & & \\
\hline \multirow[t]{4}{*}{ Firm performance } & SC1 & 0.79 & \multirow[t]{4}{*}{0.88} & \multirow[t]{4}{*}{0.66} \\
\hline & $\mathrm{SC} 2$ & 0.83 & & \\
\hline & $\mathrm{SC} 3$ & 0.71 & & \\
\hline & SC5 & 0.91 & & \\
\hline
\end{tabular}

The results from Table 3 show that the loadings, composite reliability (CR) and average variance extracted (AVE) are higher than the recommended threshold suggested by Hair, Black, Babin and Anderson (2010). The final CFA models indicate a satisfactory and are consistent with the expectation, demonstrating a better fit to the data.

The results confirmed the validity of each construct. This study then proceeds with checking the discriminant validity. This study compares the correlation of each construct with the square root of the AVE to ensure that each construct is unique and does not overlap (Chin, 1998) where the square root of AVE should be greater than the inter-construct correlation suggested by Hair et al. (2010).

Table 4. Convergent validity

\begin{tabular}{llll}
\hline Construct & Human capital & Self-efficacy & Firm performance \\
\hline Human capital & $\mathbf{0 . 7 8}$ & & \\
\hline Self-efficacy & 0.68 & $\mathbf{0 . 8 7}$ & \\
\hline Firm performance & 0.58 & 0.69 & $\mathbf{0 . 8 1}$ \\
\hline
\end{tabular}

Table 4 shows that the value of the diagonals is greater than the value of inter-construct correlations; indicating that the constructs in this study are distinct thus revealing an adequate discriminant validity. This signifies that the measurement model is considered satisfactory.

After the results are confirmed to have achieved the recommended value, the hypothesis testing was further conducted.

Table 5. Hypothesis testing results

\begin{tabular}{|c|c|c|c|c|c|c|}
\hline Hypothesis & Relationship & & Path coefficient & t-value & p-value & Decision \\
\hline $\mathrm{H}_{1}$ & $\longrightarrow$ & FP & 0.20 & 2.42 & 0.015 & Supported \\
\hline $\mathrm{H}_{2}$ & $\mathrm{HC}$ & SE & 0.68 & 10.00 & $* * *$ & Supported \\
\hline $\mathrm{H}_{3}$ & SE & FP & 0.56 & 6.17 & $* * *$ & Supported \\
\hline
\end{tabular}


Table 5 presented the results of the hypothesis testing. In the model, the human capital exerts a direct and positive effect on firm performance $(\boldsymbol{\beta}=\mathbf{0 . 2 0}, \mathbf{p}<\mathbf{0 . 0 1 5})$ and thus supporting the H1. Next, the result demonstrated that human capital exerts a significant effect on self-efficacy, $(\boldsymbol{\beta}=\mathbf{0 . 6 8}, \mathbf{p}<\mathbf{0 . 0 0 1})$ which consequently shows that the indirect effect has occurred. Thus, $\mathrm{H} 2$ is supported. Self-efficacy in turn exerts a significant positive effect on bumiputera performance $(\boldsymbol{\beta}=\mathbf{0 . 5 6}, \mathbf{p}<\mathbf{0 . 0 0 1})$ and hence supporting H3. Figure 1 indicates that the indirect path has a stronger $\mathrm{t}$-value as compared to the alternative path.

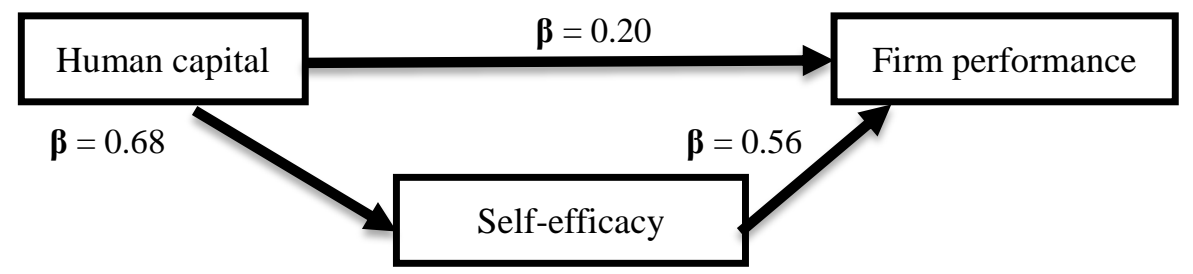

Figure 1. Structural model

Bootstrapping was performed to test the fourth hypothesis. The results in Table 5 revealed that the relationship between $\mathrm{HC}$ and FP is no longer significant, specifying that $\mathrm{HC}$ needs to pass through SE to achieve successful firm performance. This shows that self-efficacy fully mediates the relationship between human capital and bumiputera SMEs performance, hence $\mathrm{H}_{4}$ is supported.

Table 6. Standardised indirect effects - two-tailed significance (BC) (group number 1 - default model)

\begin{tabular}{llll}
\hline & HC & SE & FP \\
\hline SE & $\ldots$ & $\cdots$ & $\cdots$ \\
\hline FP & 0.38 & $\ldots$ & $\cdots$ \\
\hline
\end{tabular}

The result in Table 6 shows that the relationship between human capital and firm performance has no longer significant after the mediating effect of self-efficacy was introduced. This indicate that human capital need to pass through self-efficacy in order to achieve good firm-performance.

\section{Discussion}

The entire hypothesis has been tested and based on the results, it can be inferred that the relationship between human capital and bumiputera performance is mediated by self-efficacy. First, the significant relationship between human capital and bumiputera SMEs performance indicates that bumiputera SMEs are aware of human capital characteristics such as learning and education, experience and expertise, and innovation and creations which are pivotal to achieve good firm performance. This seems to be congruent with the past study results that the organisation will perform better with HC (Sharabati et al. 2010; Unger et al. 2011; Samad, 2013; Liu et al. 2013). The significant relationship also suggests that human capital is crucial for the bumiputera SMEs to improve their performances. The insufficient financial resources are widely known to be the main reason for the bumiputera SMEs limiting their business success. Hence, bumiputera SMEs need to find other ways to develop their human capital instead of relying solely on financial performance that could then reduce their effort to achieve firm success.

Next, this shows that the relationship between human capital and self-efficacy is significant which consequently validates that human capital can enhance self-efficacy of bumiputera SMEs. This suggests that bumiputera SMEs needs to inculcate human capital characteristics in meeting self-efficacy. For these reasons, bumiputera SMEs need to intensify SE as human capital needs to be improved. The results are consistent with the findings from previous studies that argued a relevant knowledge and skills mastery will simultaneously increase the person self-efficacy (Bandura, 1977). Other study also found that competencies, skills, and abilities are the seeds in improving self-efficacy to attain the desired goals (Raza et al. 2011). Accordingly, Machmud (2018) asserts that multiple skills increase the individual willingness to execute a certain task which then increases their willingness to make an effort. Bumiputera SMEs can use their human capital characteristic to improve their performance as well as to determine the level of effort they must put to achieve the firm goals. 
Third, the results demonstrated that self-efficacy is able to increase firm performance. This result is in accordance with findings of past studies which reported that SE positively affects firm performance (Hmieleski and Carr, 2007; Cherian and Jacob 2013; Khedhaouria, Gurău, and Torrès 2015; Barbaranelli Paciello, Biagioli, Fida and Tramontano, 2018). This indicates that the more efficacious the firm is, the high performance they presented. This specifies that bumiputera SMEs could increase the amount of effort when they are confident that they have enough expertise to meet the challenges to improve their performance. Hence, bumiputera SMEs should have necessary knowledge, skills and expertise to confidently and skillfully navigate challenging situations.

Surprisingly, this study found the insignificant relationship between human capital and firm performance after the self-efficacy was introduced. The significant and insignificant relationships might be the answers beyond the inconsistent finding from previous studies. The finding seems to be coherent where the firm might have a lot of ideas but to ensure a continuous effort for realisation of these ideas is far more important to achieve firm goals. Human capital cannot directly affect firm performance, but it should be developed in conjunction with self-efficacy to improve firm performance (Raza et al., 2011). The result of this study indicates that possessing human capital itself is insufficient for the bumiputera SMEs to sustain. The probable reason for this finding is that having a pool of human capital is indeed crucial for firms to continuously flourish in the industry. However, as the SMEs experience various challenges from inside and outside of the organisation, their belief gradually fades which negatively impact their effort.

\section{Conclusion}

The finding of this study might be useful for both academic research and practitioners. This study contributes to the existing literature in the area of human capital and self-efficacy and provides empirical studies in terms of its effect on firm performance which is lacking in the field and in case of bumiputera SMEs. First, this study validates that the sufficient human capital contributes towards self-efficacy enhancement among bumiputera SMEs. This study found that SE acts as an integral part between human capital and bumiputera SMEs performance while human capital has no direct effect on bumiputera SME performance. This also specified that; human capital is indeed crucial for firm performance only if the firm has the sufficient level of self-efficacy. Second, this study contributes to the existing theory by integrating human capital, self-efficacy and firm performance as a cohesive framework. The result in this study proves that human capital and self-efficacy presents the internal factor to achieve firm success. Strong internal factors such as human capital and self-efficacy suggest a basic to develop a sustainable firm performance. This demonstrates that bumiputera SMEs need to focus on their internal factors by intensifying human capital and self-efficacy. Since the SMEs are facing perennial challenges presented by globalisation, relying on cheap labour does not guarantee long-term sustainability or global competitive advantage (Hashim et al. 2015). Hence, it is essential for the bumiputera SMEs to discover other ways to ensure long-term sustainability. It is suggested that bumiputera SMEs need to engage in any related programs introduced by the government to develop their human capital and to fulfill the market demand. Bumiputera SMEs should involve in specific training to enhance their self-efficacy so that they can overcome obstacles with confidence in their abilities. This suggests that bumiputera SMEs need to focus on the development of an internal resource, especially in human capital besides establishing self-efficacy as a prerequisite for attaining a better performance. This research finding could be the references for the policymaker to support the bumiputera SMEs in developing their human capital and to enhance self-efficacy in the effort to promote business sustainability among bumiputera SMEs.

\section{Acknowledgement}

We would like to express our sincerest gratitude to the Ministry of Higher Education of Malaysia for the funding provided under Research Grant (600-IRMI 5/3/GIP) as well as Research Management Centre, Universiti Teknologi Mara (UiTM) for their support.

\section{References}

Abdullah, F., Hamali, J., Deen, A. R., Saban, G., \& Abdurahman, A. Z. A. (2009). Developing a framework of success of Bumiputera entrepreneurs. Journal of Enterprising Communities: People and Places in the Global Economy, 3(1), 8-24. https://doi.org/10.1108/17506200910943652

Abidin, A. Z. Z., Harun, R., \& Rahman, A. A. (2014). Identifying the issues and problems of Bumiputera Commercial and Industrial Community (BCIC) agricultural entrepreneurs in Sabah and Sarawak. Economic and Technology Management Review, $\quad 9, \quad 29-41 . \quad$ Retrieved from http://etmr.mardi.gov.my/Content/ETMR\%20Vol.9a\%20(2014)/Vol9a_4_.pdf 
Ahmad, N. H., \& Seet, P. S. (2009). Dissecting behaviours associated with business failure: A qualitative study of SME owners in Malaysia and Australia. Asian Social Science, 5(9), 98-104. https://doi.org/10.5539/ass.v5n9p98

Alam, S. S., Mohd, R., Kamaruddin, B. H., \& Nor, N. G. M. (2015). Personal values and entrepreneurial orientations in Malay entrepreneurs in Malaysia: Mediating role of self-efficacy. International Journal of Commerce and Management, 25(4), 385-401. https://doi.org/10.1108/IJCoMA-01-2013-0001

Anderson, J. C., \& Gerbing, D. W. (1988). Structural equation modeling in practice: A review and recommended two-step approach. Psychological Bulletin, 103(3), 411-423. https://doi.org/10.1037//0033-2909.103.3.411

Anwar, O. M., Husain, W. A. F. W., Bakar, J. A., \& Zakaria, Z. (2012). Legitimacy of the Malays as the Sons of the Soil. Asian Social Science, 9(1), 74. https://doi.org/10.5539/ass.v9n1p74

Azizan, S. A. (2013). Strengthening Malaysia's scientific and technological development through human capital $\begin{array}{lllll}\text { Development. Procedia-Social and Behavioral } & \text { 6ciences, }\end{array}$ https://doi.org/10.1016/j.sbspro.2013.08.465

Bandura, A. (1977). Self-efficacy: Toward a unifying theory of behavioral change. Psychological Review, 84(2), 191. https://doi.org/10.1037/0033-295X.84.2.191

Bandura, A. (1986). Social Foundations of Thought and Action: A Social Cognitive Theory. Prentice Hall: Englewood Cliffs, NJ. https://psycnet.apa.org/record/1985-98423-000

Barbaranelli, C., Paciello, M., Biagioli, V., Fida, R., \& Tramontano, C. (2018). Positivity and Behaviour: The Mediating Role of Self-Efficacy in Organisational and Educational Settings. Journal of Happiness Studies, 1-21. https://doi.org/10.1007/s10902-018-9972-4

Becker, G. S. (1975). Human Capital: A Theoretical and Empirical Analysis, with Special Reference to Education, (2nd ed., p. 22). National Bureau of Economic Research (Vol. 2). Retrieved from http://www.nber.org/books/beck75-1

Campbell, B. A., Coff, R., \& Kryscynski, D. (2012). Rethinking sustained competitive advantage from human capital. Academy of Management Review, 37(3), 376-395. https://doi.org/10.5465/amr.2010.0276

Chen, G., Gully, M. S., \& Eden, D. (2004). Validation of new general self-efficacy and self- esteem toward theorethical and empirical distinction between correlated self-evaluation. Journal of Organization Behaviour, 25(3), 375-395. https://doi.org/10.1002/job.251

Cherian, J., \& Jacob, J. (2013). Impact of self-efficacy on motivation and performance of employees. International Journal of Business and Management, 8(14), 80. https://doi.org/10.5539/ijbm.v8n14p80

Chin, W. W. (1998). The partial least squares approach to structural equation modeling. Modern Methods for Business Research, 295(2), 295-336. Retrieved from https://www.researchgate.net/publication/311766005

Chin, Y. W., \& Lim, E. S. (2018). SME Policies and Performance in Malaysia. Economic. Working Paper, Yusof Ishak Institute, 1-40. Retrieved from https://www.iseas.edu.sg/images/pdf/ISEAS_EWP_2018-3_ChinLim.pdf

Christ, S. L., Lee, D. J., Lam, B. L., \& Zheng, D. D. (2014). Structural equation modeling: A framework for ocular and other medical sciences research. Ophthalmic Epidemiology, 21(1), 1-13. https://doi.org/10.3109/09286586.2013.867508

Coff, R. W. (1997). Human assets and management dilemmas: Coping with hazards on the road to resource-based theory. Academy of Management Review, 22(2), 374-402. https://doi.org/10.5465/amr.1997.9707154063

Department of Statistics Malaysia. (2011). Economic Census: Profile of SMEs.

Economic Planning Unit, P. M. D. (2015). Eleventh Malaysia Plan 2016-2020: Anchoring growth on people. Putrajaya: Economic Planning Unit, Prime Minister's Department.

Gold, A. H., Malhotra, A., \& Segars, A. H. (2001). Knowledge management: An organizational capabilities perspective. Journal of Management Information System, 18(1), 185-214. https://doi.org/10.1080/07421222.2001.11045669

Hair, J., Black, W. C., Babin, B. J., \& Anderson, R. E. (2010). Multivariate Data Analysis: A Global Perspective. Upper Saddle River, NJ. Retrieved from https://is.muni.cz/el/1423/podzim2017/PSY028/um/_Hair_-Multivariate_data_analysis_7th_revised.pdf 
Hashim, M. J., Osman, I., \& Alhabshi, S. M. (2015). Effect of intellectual capital on organizational performance. Procedia-Social and Behavioral Sciences, 211, 207-214. https://doi.org/10.1016/j.sbspro.2015.11.085

Hilmi, M. F., Ramayah, T., Hassan, S. H., \& Mustapha, Y. (2010, October). Exploring human capital of Malaysian SMEs. In 2010 IEEE Symposium on Industrial Electronics and Applications (ISIEA) (pp. 242-247). https://doi.org/10.1109/ISIEA.2010.5679461

Hmieleski, K. M., \& Carr, J. C. (2008). The relationship between entrepreneurs psychological capital and new venture performance. Frontiers of Entrepreneurship Research, 28(4), 1-15. https://digitalknowledge.babson.edu/fer/vol28/iss4/1

Hooi, L. W., \& Ngui, K. S. (2014). Enhancing organizational performance of Malaysian SMEs. International Journal of Manpower, 35(7), 973-995. https://doi.org/10.1108/ijm-04-2012-0059

Ishak, S., Omar, A. R. C., \& Ahmad, A. (2012). Tales of the Survivors: The Bumiputera Entrepreneurs' Experience. Asian Social Science, 8(3), 25. https://doi.org/10.5539/ass.v8n3p25.

Ishak, S., Omar, A. R. C., Othman, A. S., \& Ahmad, A. (2012). Business venture of the poor: Performance and problems. International Journal of Business and Social Science, 3(16). http://www.ijbssnet.com/journals/Vol_3_No_16_Special_Issue_August_2012/18.pdf

Kadir, S. A. (2012). Amalan Nilai Islam dan Kejayaan PKS di Kelantan dan Selangor. Phd Thesis, UM. Retrieved from http://studentsrepo.um.edu.my/5749/1/COVER_\%2B_CONTENT_final_submission_Dis_2012.pdf

Kaliannan, M., Abraham, M., \& Ponnusamy, V. (2016). Effective talent management in Malaysian SMES: A proposed framework. The Journal of Developing Areas, 50(5), 393-401. https://doi.org/10.1353/jda.2016.0071

Khalique, M., \& Mansor, S. A. (2016). Intellectual capital in Malaysian hotel industry: a case study of Malacca. International Journal of Business Performance Management, 17(1), 103-116. https://doi.org/10.1504/IJBPM.2016.073348

Khalique, M., Shaari, N., Abdul, J., \& Isa, A. H. B. M. (2018). Impact of Intellectual Capital on Organizational Performance of ICT SMEs in Penang, Malaysia. College of Management Science, 13(2). Retrieved from https://www.researchgate.net/publication/329862618_Impact_of_Intellectual_Capital_on_Organizational_Perfo rmance_of_ICT_SMEs_in_Penang_Malaysia

Khalique, M., Shaari, N., Abdul, J., Isa, A. H. B. M., \& Ageel, A. (2011). Role of intellectual capital on the organizational performance of electrical and electronic SMEs in Pakistan. International Journal of Business and Management, 6(9). https://doi.org/10.5539/ijbm.v6n9p253

Khan, E. A., \& Quaddus, M. (2018). Dimensions of human capital and firm performance: Micro-firm context. IIMB Management Review, 30(3), 229-241. https://doi.org/10.1016/j.iimb.2018.05.004

Khedhaouria, A., Gurău, C., \& Torrès, O. (2015). Creativity, self-efficacy, and small-firm performance: the mediating role of entrepreneurial orientation. Small Business Economics, 44(3), 485-504. https://doi.org/10.1007/s11187-014-9608-y

Liu, N., \& Wang, C. (2013). Achieving organizational effectiveness through human capital acquisition practices. The moderating effects of environment turbulence and knowledge sharing climate. Journal of Human Resource Management, $\quad 13(3), \quad 1-25 . \quad$ Retrieved from http://www.airitilibrary.com/Publication/alDetailedMesh?DocID=10265309-201309-201310140014-201310140 014-1-25h

Luszczynska, A., Gutiérrez-Doña, B., \& Schwarzer, R. (2005). General self-efficacy in various domains of human functioning: Evidence from five countries. International Journal of Psychology, 40(2), 80-89. https://doi.org/10.1080/00207590444000041

Luthans, F., Luthans, K. W., \& Luthans, B. C. (2004). Positive psychological capital: Human and social capital. Business Horizons, 47(1), 45-50. https://doi.org/10.1016/j.bushor.2003.11.007

Machmud, S. (2018). The influence of self-efficacy on satisfaction and work-related performance. International Journal of Management Science and Business Administration, 4(4), 43-47. https://doi.org/10.18775/ijmsba.1849-5664-5419.2014.44.1005 
Mohamad, A., Rizal, A. M., Quoquab, F., Juhdi, N. H., \& Sahimi, M. (2016). Restarting after business discontinuity among Bumiputra small and medium enterprises. European Journal of Economics and Business Studies, 2(1), 259-270. https://doi.org/10.26417/ejes.v2i1.p259-270

Mohd, R., Kamaruddin, B. H., Hassan, S., Muda, M., \& Yahya, K. K. (2014). The important role of self-efficacy in determining entrepreneurial orientations of Malay small scale entrepreneurs in Malaysia. International Journal of Management Studies, 20(1), 61-82. Retrieved from ijms.uum.edu.my/images/pdf/21no1/4ijms21.pdf

Munjuri, M. G., \& K'Obonyo, P. (2015). Human capital, employee empowerment and performance of commercial banks and insurance firms in Kenya. International Journal of Arts and Commerce, 4(6), 163-181. Retrieved from https://ijac.org.uk/images/frontImages/gallery/Vol._4_No._6/17._163-181.pdf

Ngah, R. (2011). The relationship of intellectual capital, knowledge sharing, innovation and organizational performance of Malaysian SMEs. Unpublished doctoral dissertation, Universiti Malaya, Malaysia. Retrieved from

https://www.researchgate.net/publication/228359747_The_relationship_of_intellectual_capital_innovation_and _organizational_performance_a_preliminary_study_in_Malaysian_SMEs

Omar, C. M. Z., \& Azmi, N. M. N. (2015). Factors affecting the success of Bumiputera entrepreneurs in small and medium enterprises (SMEs) in Malaysia. International Journal of Management Science and Business Administration, 1(9), 40-45. https://doi.org/10.18775/ijmsba.1849-5664-5419.2014.19.1004

Oyugi, J. L. (2016). The mediating effect of self-efficacy on the relationship between entrepreneurship education and entrepreneurial intentions of university students. Journal of Entrepreneurship, Management and Innovation, 11(2), 31-56. https://doi.org/10.7341/20151122

Pihie, Z. A. L., \& Bagheri, A. (2013). Self-efficacy and entrepreneurial intention: The mediation effect of self-regulation. Vocations and Learning, 6(3), 385-401. https://doi.org/10.1007/s12186-013-9101-9

Radzi, K. M., Nor, M. N. M., \& Ali, S. M. (2017). The impact of internal factors on small business success: A case of small enterprises under the Felda scheme. Asian Academy of Management Journal, $22(1), 27$. https://doi.org/10.21315/aamj2017.22.1.2

Rahim, A., Atan, R., \& Kamaluddin, A. (2017). Human Capital Efficiency and Firm Performance: An Empirical Study on Malaysian Technology Industry. SHS Web of Conferences, 36(00026), 1-11. https://doi.org/10.1051/shsconf/20173600026

Ramlee, S., \& Berma, B. (2013). Financing gap in Malaysian small-medium enterprises: A supply-side perspective. South African Journal of Economic and Management Sciences, 16(5), 115-126. https://doi.org/10.4102/sajems.v16i5.641

Raza, S. A., Zia, S., Naqvi, S. A. H., \& Shaikh, F. M. (2011). Human and social capital development for self-efficacy of university graduates: Bases for development of society. Asian Social Science, 7(9), 244. https://doi.org/10.5539/ass.v7n9p244

Sabiu, I. T., \& Abdullah, A. (2018). Differences in gender: Does it exist in Bumiputra entrepreneurs? Entrepreneurship and Structural Change in Dynamic Territories. https://doi.org/10.1007/978-3-319-76400-9_8

Said, R., Joseph, C., Sidek, N. Z. M., Zawawi, A., Zakaria, Z., Ladisma, M., \& Omar, N. (2018). Development of Bumiputera communicated identity index for Malaysian statutory bodies. International Journal of Academic Research in Business and Social Sciences, 8(3), 198-209. https://doi.org/10.6007/IJARBSS/v8-i3/3914

Samad, S. (2013). Assessing the contribution of human capital on business performance. International Journal of Trade, Economics and Finance, 4(6), 393-397. https://doi.org/10.7763/IJTEF.2013.V4.324

Schultz, T. W. (1961). Investment in human capital. The American Economic Review, 1-17. Retrieved from https://link.springer.com/article/10.1023/A:1006884930135

Shane, S., Locke, E. A., \& Collins, C. J. (2003). Entrepreneurial motivation. Human Resource Management Review, 13(2), 257-279. https://doi.org/10.1016/S1053-4822(03)00017-2

Sharabati, A. A. A., Naji Jawad, S., \& Bontis, N. (2010). Intellectual capital and business performance in the pharmaceutical sector of Jordan. Management Decision, 48(1), $105-131$. https://doi.org/10.1108/00251741011014481 
SMECorp. (2017). SME Annual Report, 2016/2017. Retrieved from http://www.smecorp.gov.my/images/SMEAR/latest/Chapter3.pdf

Stajkovic, A. D., \& Luthans, F. (2003). Behavioral management and task performance in organizations: conceptual background, meta-analysis, and test of alternative models. Personnel Psychology, 56(1), 155-194. https://doi.org/10.1111/j.1744-6570.2003.tb00147.x.

Thaker, M. T., Asmy, M., \& Mohamed, M. O. (2015). The challenges of micro enterprises in Malaysia and the prospect for integrated cash waqf micro enterprise investment (ICWME-I) model. IIUM Press, 18(2), 111-130. https://doi.org/10.22146/gamaijb.12565

Tunggak, B., Salamon, H., \& Abu, B. (2011). Training and long life learning for Islamic entrepreneur. Jurnal Teknologi, 55(Sains Sosial), 121-144. https://doi.org/10.11113/jt.v55.84

Unger, J. M., Rauch, A., Frese, M., \& Rosenbusch, N. (2011). Human capital and entrepreneurial success: A meta-analytical review. Journal of Business Venturing, 26(3), 341-358. https://doi.org/10.1016/j.jbusvent.2009.09.004

Whah, C. Y., \& Guan, B. T. C. (2017). Malaysia's protracted affirmative action policy and the evolution of the Bumiputera Commercial and Industrial Community. SOJOURN: Journal of Social Issues in Southeast Asia, 336-373. https://doi.org/10.1355/sj32-2d

Yusuf, M. (2011). Investigating relationship between self-efficacy, achievement motivation, and self-regulated learning strategies of undergraduate students: a study of integrated motivational models. Procedia-Social and Behavioral Sciences, 15, 2614-2617. https://doi.org/10.1016/j.sbspro.2011.04.156 